Tér és Társadalom 3. 1991•2-3: 161-163

\title{
KÖNYVJELZÖ
}

\section{A PROFESSZIONÁLIS TÁRSADALOM FELEMELKEDÉSE: ANGLIA 1880 ÓTA}

\author{
Harold Perkin (1990) The Rise of Professional Society: England since \\ 1880, Routledge, London and New York
}

Harold Perkin, az angol társadalomtörténeti kutatások iskolateremtỏ alakja, újabb könyvében a korábbi nagysikerư kötetének - The Origins of Modern English Society - folytatására vállalkozott. Elổzổ könyvében az angol társadalmat az ipari forradalom kezdeteteitól 1880-ig elemezte. Ez az idôszak a kapitalizmus kialakulásának és megerốsödésének a korszaka volt. Újabb könyvének témája nemcsak idốbelileg vezet új korszakba, hanem tartalmilag is. A XIX. század végétốl maga a társadalom alakult át gyökeresen. Jellemzó folyamat, hogy egyre kevésbé a gazdasági tốke - Marx által leírt - logikája határozza meg a gazdaság és társadalom alapvetố jellemzốit. , Egy komplex, egymástól kölcsönösen függó társadalomban a piac képtelen igazságosan vagy hatékonyan biztosítani a fóbb alapvetố szolgáltatásokat. Így elkerülhetetlenné vált a közpénzekból finanszírozott szakmák létrejötte." (15. oldal) A viktoriánus korszak víziójával szemben - mely a vállalkozóra és az ipari tốkére helyezte a hangsúlyt most a jól képzett szakember vált ideállá. $\mathrm{A}$ társadalom egyre inkább a szakmai megalapozottságot és tudást helyezte elốtérbe. A gazdasági tốke hatékony mứködtetéséhez a gyorsulo mứszaki-technikai fejlődés miatt egyre magasabb szintứ , kulturális tốke" szükséges. Ennek hiányában a gazdasági tốke gyorsan elve- szítheti értékét. A fenti jelenségeket már sokan leírták. Perkin azonban ezek társadalmi következményeit átfogó, elméleti keretben vizsgálja. Szerinte a társadalmi szervezốdés új elve jött létre, mely a társadalmi erôforrásokért versengố, egymással rivalizáló és karrierre épülố hierarchiákon alapul. Ezen belül a legélesebb verseny az államhoz kötôdố professzionális szakmák: az állami közszféra szakemberei és az erổsödổ magáncégek, részvénytársaságok menedzserei között bontakozik ki.

Természetesen ennek̉ az új társadalmi mechanizmusnak és az ezt megtestesíto új társadalmi rétegnek a kialakulása hosszabb idốt vett igénybe. A kötet által vizsgált korszak elején - az 1880-as évek - még a gazdasági tỗkére épülổ osztálytársadalom csúcspontjáról van szó. A szerzó nagyon érdekes elemzést ad a burzsoáziáról. Rendkívül érzékletesen írja le például a burzsoázia arisztokratizálódását. Ez nem csak abban nyílvánult meg, hogy e csoport felsố rétege formailag is belépett az arisztokrácia sorába. 1886-1914 között az új, fổnemesi rangot nyert 200 személy között több mint 70 az ipar, a bank és kereskedelmi szféra nagytốkései közé tartozott. Természetesen rajtuk kívül a burzsoázia szélesebb csoportjait is megérintette az arisztokrata életmód diszkrét bája. Sokan vásároltak vidé- 
ki kastélyokat, $\mathrm{s}$ a rókavadászatokon lelkesen lovagoltak együtt arisztokrata szomszédaikkal. Perkin azonban ezt - a Wiener által karikírozott tendenciát - sokkal árnyaltabban ábrázolja, a folyamat másik oldalát is észreveszi. Nevezetesen a földbirtokos arisztokrácia egy része aktívan bekapcsolódott az ipari és kereskedelmi vállalkozásokba. ,,Az angol földbirtokos osztály soha sem vetette meg a profitszerzést, legyen szó mezőgazdaságról, bányászatról, városfejlesztésrốl, közlekedési vállalkozásokról, mint pl.; utak, csatornák, vasútak és kikötớk, sốt gyapotfeldolgozó üzemek és acélmưvek... Bárhol, ahol jövedelmet remélhettek." (119. o.) A szerzổ szerint nem az arisztokrácia volt a legfontosabb propagálója az ipar-ellenes, állítólagos arisztokratikus értékrendnek, hanem a formálódó professzionizmus , ,papjai”. Ez az új értékrend a hírneves public schoolok-ban, illetve Oxford és Cambridge egyetemein formálódott ki. Ezen értékrend szerint a professzionális szolgáltatások fölötte állnak mind az arisztokrata tétlenségnek, mind a tốke és pénz harácsolásának.

Perkin hangsúlyozza, hogy a közeledés ellenére nem lehet a foldbirtokos arisztokrácia és burzsoázia bármiféle összeolvadásáról beszélni. Ha volt igazán nyílvánvaló különbség a nagybirtokosok és az új milliomosok között, akkor ez származásukban és iskolázottságukban tükrözôdött. A nagybirtokos arisztokrácia tagjai túlnyomó többségben magániskolákat látogattak. Ezen belül 1880-1890 között 81\%-uk, 1900-1919 között 73\%-uk Etonba ment tanulni. Az elốbb említett két idószakban mintegy $36-40 \%$-uk Oxfordba, vagy Cambridge-be ment egyetemre. A nem földbirtokos milliomosok a társadalom jóval szélesebb rétegeiból toborzódtak. A burzsoá milliomosoknak 13-18\% -a származott földbirtokos családból. Döntố többségük, (56\%) gazdag vállalkozó családok vagyonából indíthatta vállalkozását. Ellentétben a hiedelmekkel, csak 25-30\% volt az un. self-made man. Bár az új milliomosok jóval kisebb arányban (25\%) nevelődtek Etonban, mint a földbirtokos arisztokrácia gyermekei, mégis meglepốen nagy arányban látogatták a többi híres magániskolát (53-62\%). A XIX. század végén a gazdasági tôke képviselổit nem csak a munkásmozgalom fenyegette, hanem a hosszabb távon sokkal hatékonyabbá váló szellemi középosztály is.

A professzionális ideál már az I. világháború elốtt is egyre jobban befolyásolta a munka és tốke viszonyát. A társadalmi feszültségek enyhítése érdekében az I. világháború elốtt csírájában már megjelenik a jóléti állam. A társadalmi biztonság növelése, az oktatási lehetổségek bớvítése és az egészségügyi ellátás javítása a jövedelmek újraelosztását igényelte. A progresszív adózás egyre mélyebben érintette az , ,abszolút" magántulajdon szentségét. A városi infrastruktúra fejlesztését egyre inkább a hierarchikus hivatalnoki szervezetek vették kézbe. Az I. világháború szintén hozzájárult a professzionális ideál további megerôsödéséhez. A hadiipari termelés érdekében a magántulajdont, a profitmotívumot korlátozva - az állam egyes ágazatokat közvetlen ellenốrzése alá vont.

A növekvố társadalmi juttatásokhoz a progresszív adózás teremtette meg a forrásokat. 1909 elốtt ezt az adózási formát nem alkalmazták. 1938-ban viszont - jelezve a progresszivitás erổteljes voltát - az 1\%-ot képviselố legmagasabb jövedelmủek 17,1\%-os részesedése az adózás elốtti jövedelmekbốl az adózás után, vagyis ténylegesen $11,7 \%$-ra csökkent. 1949-re tovább erôsödött a progresszivitás. A legmagasabb jövedelemmel rendelkezố $1 \%$ részesedése a jövedelmekbớl 10,6\%-ról, az adózás után 5,8\%-ra csökkent. Ugyanekkor a felsố $10 \%$ részesedése majdnem 1/6-dal csökkent a progresszív adó miatt (32,1\%-ról 25,7\%-ra). Jellemzô, hogy a kü- 
lönféle társadalmi juttatások 1910-ben még csak a nemzeti jövedelem 4,2\%-át tették ki, viszont 1930 -ra már közel $20 \%$-át. A bérezés elvében is változás következik be. Mindegyik foglalkozás - beleértve az üzleti élet irányítóit is - úgy véli, hogy javadalmazását inkább társadalmi funkciójához kell kapcsolni, mint a munkaerô értékének piaci fluktuációjához. A II. világháború után; , ,Éppen úgy, ahogy az ipari társadalom feleslegesnek tekintette a földbirtokost, ugyanúgy a poszt-indusztriális társadalomban a professzionális bürokrata, $\mathrm{s}$ nem kevésbé a részvénytársasági szféra is feleslegesnek tekinti a magántớkést..." (289. o.) A professzionalizmus társadalmi ideálja a II. világháborí utáni korszakban szorosan összekapcsolódott a keynes-i gazdaságpolitikával. A professzionalizmust képviselố ,,szellemi középosztály" megerôsödése összefüggésben állt a brit gazdaság mélyreható átalakulásával. 1909-ben a 100 legnagyobb cég az ipari termelés 15\%-át adta. 1970-re ez az arány 45\%-ra nốtt. A növekvố vállalat-méret bonyolultabb vállalati irányítási hierarchiát igényel; s egyúttal automatikusan növeli a menedzserek szerepét. A nagy, nemzetközi jellegưvé váló monopóliumok irányítása, a specializált szakemberek ezreinek bürokratikus hierarchiába rendezett csoportjait igényelte. Ez egyúttal azt is jelentette, hogy ,,az óriási, és egyúttal mások tulajdonában lévớ tốkék feletti közvetlen ellenỡrzés a bürokratikus hierarchiák karrier-menedzsereinek a kezébe került." (295.o.) Ahogy Berle 1954-ben szellemesen megfogalmazta: , ,a tốke és a kapitalizmus marad, viszont a tốkés fokozatosan háttérbe szorul."

A 70-es évek elején a stagnáció és infláció együttes jelentkezése - mely Keynes doktrínája szerint kizárja egymást - a monetarista gazdaságpolitika híveinek fokozatos megerốsödését eredményezte. A monetarista gazdaságpolitikát, a hiedelmekkel ellentétben, a munkáspárti kormány alkalmazta elốször 1976-ban. A thatcheri korszakban éles kampány indult a bürokrácia ellen, az állami beavatkozás visszafogására és a jóléti intézkedések lefaragására. Gyors ütemben privatizálták a sikeres állami vállalatokat. Azonban az ,,...az apály hulláma sokkal kevesebbet vett vissza, mint az elsố pillantásra látszik. Például az államosított iparágak privatizációja az ellenổrzést az állami szféra helyett a magán szféra bürokratáira ruházta át, vaşy ami még általánosabb, ugyanazokat az állami menedzsereket ugyanoda, a most már privatizált vállalatok élére nevezték ki. Vagyis a továbbiakban már nem a kormányzatnak tartoznak felelősséggel, hanem a részvényeseknek, akik viszont túlzottan nagyszámúak és megosztottak ahhoz, hogy ellenốrizhetnék ốket. A jóléti államot nem rombolták le, hanem inkább szelektívebbé tették. Ez azonban csak a szociális igazgatásnak ad több munkát és több hatalmat." (289. o.) Vagyis Perkin teljesen új megközelítésben tárgyalja a thatcherista korszakot. Szerinte végeredményben nem történt más, mint hogy a két egymással rivalizáló bürokrata csoport közül most a magánszférában tevékenykedó menedzser-réteg került fölénybe. Egyúttal a keynesi korszakban domináns állami bürokraták és menedzserek háttérbe szorultak. A szerzố rámutat a bekövetkezett változások regionális következményeire is. „,Az Észak és Dél közötti szakadás - legalábbis részben - a professzionalista középosztályon belüli szakadás is." (517. o.)

A brit politika fố kérdése, hogy a két professzionalista ideál közül melyik gyổzedelmeskedik. Perkin szerint a legfontosabb, hogy a rivális ideológiák legszélsốségesebb formáit elkerüljük, azaz; a részvénytársasági neofeudalizmust és az autoritér államot. A magyar gazdaság és társadalom mostani modellkeresésében ez számunkra is intớ tanulság.

Timár Lajos 